\title{
A radical proposal for direct democracy in large societies
}

\author{
Proposta radical para democracias \\ diretas em grandes sociedades
}

JOHN ASIMAKOPOULOS*

RESUMO: Argumenta-se que a democracia direta é atingível, mas apenas em formas que se conectam às experiências da vida diária. Ao modificar as instituições existentes de governança é pragmaticamente possível alcançar uma sociedade que se assemelhe a utopias distantes. Uma proposta baseia-se no argumento de que todos os sistemas eleitorais são inerentemente fraudulentos sob qualquer regime. Pelo contrário, a democracia direta só pode fornecer igualdade substantiva. Portanto sugere-se que os poderes legislativo e judicial devem ser preenchidos por sorteio, deixando as demos como o executivo através de votação pela Internet modelada no princípio de proposições do estado.

PALAVRAS-CHAVE: democracia; eleições; teoria social; sistemas políticos.

ABSTRACT: It is argued direct democracy is attainable but only in ways that connect to the experiences of daily life. By modifying existing institutions of governance it is pragmatically possible to achieve a society resembling distant utopias. One proposal is based on the argument that all electoral systems are inherently fraudulent under any regime. Rather, direct democracy alone can provide substantive equality. Therefore it is suggested legislative and judicial branches be filled by lottery while leaving the demos as the executive through internet voting modeled on the principle of state propositions.

KEYWORDS: democracy; elections; social theory; political systems.

JEL Classification: D7; D72.

Representative democracy has resulted in a system where those who own the means of production effectively control the political process (Asimakopoulos, 2011; Domhoff, 1975, 2010; Mills, 2000 [1956]). Consequently most public policy tends to privilege corporate interests over those of the community and the environment. Under a political system of direct representation such corporate dominance could be

\footnotetext{
* Full Professor of Sociology at the City University of New York. Email: jasimakopoulos@ transformativestudies.org. Submitted: 13/June/2012; Approved: 18/March/2015.
} 
significantly reduced if not eliminated. What then is direct democracy and can it work in a modern, large-scale, society, who would be opposed to it, and why is representative democracy illusory. These are some questions that will be addressed here.

\section{WHAT IS DIRECT POLITICAL DEMOCRACY?}

A basic definition of direct democracy is each citizen represents themselves and votes directly on issues confronting the community. This is in stark contrast to all forms of representative democracy where we vote for the congressperson or senator who will vote in our best interest for us-without consulting each of us first. Direct democracy is what today is referred to as libertarian socialism including anarchism. The very idea upon which libertarian socialism is founded is that every person in the community represents themselves and votes directly with the community on matters related to its governance. This should also indicate that anarchism is not chaos, as is often mistaken in the popular usage of the term. Rather, anarchy means a lack of a central authority because authority is decentralized and disbursed among the demos. This type of society would be orderly and more so than today's communities, but based on collective direct governance. Furthermore, it is erroneous to assume that no government means no administrative apparatus. In fact, administrative "bureaucracies" would still exist to execute and administer the decisions of the demos.

Anarchism is one of the most diverse theoretical perspectives. It includes anarcho-communism, anarcho-Marxism, syndicalism, participatory economics, mutualism, etc. all of which are commonly referred to as libertarian socialism. As for the fundamental principles of anarchist forms of societal organization Guerin (1970), Rocker (1938), and Ward (1982) provide an excellent review. Kropotkin (2005 [1892]) was one of the first to develop an anarcho-communist variant.

A key goal of libertarian socialists is the elimination of the state in favor of self-organization, a form of direct political democracy, arguing that any form of state government by definition results in the suppression of the many by the few. This is argued to be true of representative democracies as well in that they too are dominated by elites, therefore will not benefit the working class (Domhoff, 2010). Such democracies, however, do provide some benefits as a result of working-class participation compared to an overt dictatorship but these are seen as minor and perpetually under attack by elite interests (Guerin, 1970; Rocker, 1938).

\section{THE PROBLEM WITH REPRESENTATIVE DEMOCRACY IN CAPITALIST SOCIETY: ALL ELECTIONS ARE FRAUDS}

If we assume that direct democracy is possible in a modern society, then why are we fixated on representative systems? Because this is a clever way for capitalists to circumvent substantive democracy replacing it with an illusory democratic sys- 
tem that they can manipulate while appeasing the masses, lending the system a semblance of legitimacy (Chomsky, 1989, 2002). I, as many others, argue political structures, absent direct democracy, are irrelevant in that they are post hoc reflections of elite interests. Those that control societal resources typically wish to erect political structures that represent and institutionalize their class interests, including representative political systems. Consequently, those that control society's productive resources can do so only by controlling its political administration which cannot happen under direct democracy.

The founding fathers who were distrustful of direct democracy, as an example, did not dream-up the separation of powers out of concern for safeguarding democracy. Instead, they were clearly afraid that the landless "rabble" would use democracy to vote away their wealth (Bouton, 2007). This is why Bouton suggests Robert Morris, Hamilton's mentor who financed the Revolutionary War, organized the constitutional convention to move the country from a confederation to a federation controlled by what Morris approvingly called "moneyed people" with Hamilton wanting to promote the interests of commerce and industry through a strong central government. If democracy was used to challenge elite interests, the Supreme Court would function as a safe-stop. If that failed too, there was the military. What was established by the slave-owning White Anglo-Saxon Protestant founding fathers was more accurately a landed oligarchy.

To this day the United States' political system is ripe with influence and corruption often legalized by the system itself. For instance, the Supreme Court allowed corporations to spend unlimited amounts in the political process in its 2010 Citizens United v Federal Election Commission ruling resulting in the formation of super PACs (Political Action Committees). Now, a corporation that is a fictional legal person is permitted to influence the political process. Problem is the corporation is not a person. It is managed by individuals who, as such, can vote and donate their own money if they wish to. Clearly, the reason behind the decision was to unleash the financial power of the elite who own these corporations to manipulate political outcomes, often anonymously. This circumvents the fundamental democratic principle of one person one vote.

Furthermore, why can wealthy individuals spend unlimited funds on politicians or for their own campaigns? Although she eventually lost, in 2010 "Meg Whitman, the Republican candidate for governor in California, passed a milestone [...] investing \$119 million of her own money into her campaign, breaking a record held by Mayor Michael R. Bloomberg of New York" (Nagourney, 2010). Then there are the legalized "auctions" to purchase politicians, e.g., buying tickets to fundraising events that cost tens of thousands of dollars, amounts far beyond the reach of the majority. In 2010 president Obama attended a NJ fundraiser " [...] at the home of Michael Kempner, CEO of MWW Group, an East Rutherford-based public relations and lobbying firm. The invitation said the guest list is limited to 50, at $\$ 30,400$ a plate" (Friedman, 2010). Compare this to a federal minimum wage of $\$ 7.25$ and an average annual wage in 2009 of $\$ 48,984$ (Bureau of Labor Statistics Table 4).

Why are executives appointed to government oversight positions for the indus- 
tries they came from? Is this not an obvious conflict of interest? While former treasury secretary Henry Paulson was the CEO of Goldman Sachs, he requested the deregulations from the Securities and Exchange Commission (SEC) which caused the 2008 meltdown. He convinced the SEC to allow major financial institutions to increase their leverage and risk exposure by exempting them from the net capital rule that required them to hold higher capital reserves. As treasury secretary, he then asked for the epic bailout of 2008, benefiting financial corporations, which were his true clients. The hubris continued when treasury secretary Paulson privileged his former employer, Goldman Sachs, both in terms of the amount of contact and decisions made, such as allowing Goldman's rival Lehman Brothers to collapse, during the financial melt-down (Morgenson and Van Natta, 2009). Paulson was followed by treasury secretary Tim Geitner, another Goldman Sachs executive. Former New Jersey Governor Jon Corezine was a CEO of Goldman Sachs. Former vice president Dick Cheney was the CEO of Halliburton, the company whose subsidiary won billions of dollars through no-bid contracts because of the war in Iraq-a war he orchestrated through propaganda. Former president George W. Bush is a former oil man who is tied to the Saudi monarchy. New York City mayor Mike Bloomberg, who violated his own term limits, owns a media empire. Former president Bill Clinton made hundreds of millions in speaking fees after leaving office in addition to significant donations for his presidential library from governments and executives he met as president. Are these corporate civil servants capable of being stern and fair in regulating industries that either own them or they own themselves?

Of course, one could argue there have been examples of elites seemingly opposing their class interests, e.g., Teddy and Franklin Roosevelt who pursued significant regulatory reforms. There are two problems with this. One, these are exceptions to the rule therefore not of much use for the working class. Second, these elites acted because of serious pressure from below indicating the value of direct action. For example, Franklin Roosevelt was trying to save the very system of capitalism from revolution therefore he was acting in not against his class interests (Asimakopoulos, 2011).

According to one journalist in 1933, "capitalism itself was at the point of dissolution". Bank runs and general civil unrest were reaching a crisis point:

For the first time since the Civil War, armed men patrolled the entrances to federal buildings, while machine gunners perched on rooftops... Unrest was already growing in the farm belt, where mobs had broken up bankruptcy auctions. Four thousand men had occupied the Nebraska statehouse and five thousand stormed Seattle's county building. The governor of North Carolina predicted a violent revolution, and police in Chicago clubbed teachers who had not been paid all school year (Alter, 2006, pp. 3-4)

As a result, it was anticipated that Roosevelt's inauguration speech on March 4, 1933 would declare martial law to keep the nation from revolution. This led the 
New York Herald-Tribune on March 5 to print "FOR DICTATORSHIP IF NECESSARY", with other papers running similar headlines (Alter, 2006 p. 4).

It all comes down to this: more money equals power equals greater chances of getting what you want which is a fundamental violation of the democratic principle of one person one vote versus one person billions of dollar-votes. But, if the outcome of a political process can be determined by resource expenditures, then the outcome will be fundamentally undemocratic regardless of the political system's nominal name, e.g., democracy will become interchangeable with fascism in substance. Take campaign financing and sources of major contributions. Even president Obama was beholden to Wall Street rather than Main Street during his 2008 presidential campaign (see Table 1). No wonder his economic team, all with extensive Wall Street ties, was a carryover from the Republican administration that preceded his.

Table 1: Top donors to Barack Obama in the 2008 election

\begin{tabular}{|l|c|}
\hline University of California & $\$ 1,591,395$ \\
\hline Goldman Sachs & $\$ 994,795$ \\
\hline Harvard University & $\$ 854,747$ \\
\hline Microsoft Corp. & $\$ 833,617$ \\
\hline Google Inc. & $\$ 803,436$ \\
\hline Citigroup Inc. & $\$ 701,290$ \\
\hline JPMorgan Chase \& Co. & $\$ 695,132$ \\
\hline Time Warner & $\$ 590,084$ \\
\hline Sidley Austin LLP & $\$ 588,598$ \\
\hline Stanford University & $\$ 586,557$ \\
\hline National Amusements Inc. & $\$ 551,683$ \\
\hline UBS AG & $\$ 543,219$ \\
\hline Wilmerhale LIp & $\$ 542,618$ \\
\hline Skadden, Arps et al. & $\$ 530,839$ \\
\hline IBM Corp & $\$ 528,822$ \\
\hline Columbia University & $\$ 528,302$ \\
\hline Morgan Stanley & $\$ 514,881$ \\
\hline General Electric & $\$ 499,130$ \\
\hline US Government & $\$ 494,820$ \\
\hline Latham \& Watkins & \\
\hline
\end{tabular}

Source: www.opensecrets.org 
Another sign of decay is a system under which those in charge remain the same for long periods of time. Career politicians are often defended arguing their experience is invaluable, which is blatantly untrue. Such politicians are either dictators, e.g., former "president" Mubarak or, in the case of representative democracy, entrenched with the sole purpose of maintaining their privilege. To do so necessitates appeasing those with resources who end up deciding the outcomes of political elections with their money. However, those with the resources are the top one to five percent either as individuals or behind the veil of a corporation. The majority has nothing to contribute and is treated accordingly in the legislative process.

It is argued that any system that is based on elected representatives, as with the legislature and executive, or appointed, as with the Supreme Court, will be corrupted. With direct democracy such systemic corruption and manipulation of the process is minimized or next to impossible since everyone votes for themselves. This is why to the elite and the social institutions they dominate, e.g., the mass media, schools, and so on democracy is always understood as indirect when in fact direct systems are both feasible and more democratic. The masses simply cannot be trusted to acquiesce to elite interests through substantive democracy.

\section{CAN DIRECT DEMOCRACY WORK IN LARGE MODERN SOCIETIES?}

A form of direct democracy is possible in modern, large-scale, societies although not based on the ideal type. Let us use the United States as an example of how this could work. First, it is unrealistic to advocate a return to local, small-scale, autonomous economies as is so often proposed by many ideological Lefties. For example, when asked about many primitive-anarchists who want to go back to growing one's own food, Chomsky stated, they are utterly utopian and that that would lead to the death of many people who in a modern society do not have the skills or ability to do so including himself. Modern standards of living are made possible by the global administration of resources irrespective of the ideological underpinnings. This is so because of the "rationalization" that the management of global resources has undergone. Locally based economies may work well in agrarian or subsistence societies but would entail a dramatic downgrading in the living standards of people in the developed world. How do we convince them to turn back the development clock? We cannot which is why such ideologies seeking to dismantle the global economy versus changing the basis upon which it is organized and operates, i.e., private/capitalist to public/communal are bankrupt practically speaking. Rather, in keeping with pragmatism, we need to question not if but how to deal with large-scale management of global resources in an egalitarian and sustainable manner.

Second, bureaucracies are distinct from a government (Max Weber, 1978 [1922]). Consequently, it is important to understand that bureaucratic administrative structures, e.g., a department of education would continue to exist. However, 
this type of governance must not be confused with a state government per say. Rather this is the professional technocratic staff that will facilitate public decisions. It is a form of stateless governance.

This raises the old question of power relative to permanent professional bureaucracies. Specifically, it is often the case that the expert staff will use their knowledge to wield power, e.g., by shaping the debate over policy in a manner that can influence the decision makers. This is especially the case with volunteer or temporary legislators who may lack the expertise and or the institutional history of the structures that they are overseeing. This however is a problem related to organizational structures in general regardless of ideology. Max Weber had identified this fact when referring to the "iron cage" (1978 [1922]). Specifically, he realized that large-scale operations are inevitable in modern "rationally" oriented societies necessitating a bureaucracy resulting in the aforementioned problems with the staff - a conclusion that was said to contribute to his chronic depression. One may argue bureaucracies would not be required in small-scale autonomous communities which is true. But, as stated, the return to small-scale local societies is not pragmatic. Modernity cannot be reversed which brings us back to the issue of a professional bureaucracy which although related is not the exact focus of this paper.

In general, local governments can practice direct democracy as demonstrated by the Juntas de Buen Gobierno (Councils of Good Government) set-up by the Zapatistas in Mexico. In order to protect against corruption the Juntas de Buen Gobierno rotate service on the council with each citizen within the jurisdiction required to serve for two weeks, after which a new council is organized. Unfortunately, this is not possible at the next governance level. How could millions meet in a single space to discuss legislation? Even if this were possible in physical or internet space, there would be a cacophony of voices. Technically, this was the justification behind representative democracy. Libertarian socialists who accept the need for larger-scale societal organization concede to this point which is why they derive systems where representatives are selected to join assemblies at higher levels with various safeguards such as instant recall. But this raises once more the issue of how representative the selected individuals would be if based on some form of election or appointment. For example, how would such selection avoid the problems with existing democratic systems which devolve into "personality" contests - think of Ronald Reagan. In fact, the whole point of direct democracy is that it is as representative of the peoples' will as possible, which does not result from "likability" selection criteria.

Representative democracy based on theoretically unbiased elections also attempts to reflect the will of the people as closely as possible. But, if the purpose of a democratic system is to reflect as closely as possible the overall will of the entire demos we are really talking about a system of representativeness as used in statistical terms. This has prompted various theorists to propose systems of random selection of decision makers (Burnheim, 2006; Carson and Martin, 1999). Statistically, a representative sample will reflect the entire population from which it came from. 
This is a fact that many scholars who are not mathematically inclined seem not to comprehend or accept (assuming the statistical process is monitored and certified as fair and scientific - which is not the focus of this paper). Such a representative sample cannot be generated from voting even though in the popular usage of the word the elected officials are considered to be representative of the electorate. For example, who represents those that did not register to vote, or those who did but did not actually vote? These two groups alone typically represent over $50 \%$ of the electorate in US presidential elections (The United States Elections Project). Furthermore, who represents the mentally ill, prisoners, hospitalized, disenfranchised, and the list goes on and on. For example, political scientists have found that the typical consistent voter in the United States is older, White, Anglo-Saxon, Protestant, well educated, and materially better off, hardly a reflection of the nation.

On the other hand, a statistically representative sample does represent the entire population. However, statistically representative samples are not generated through elections but by random selection, meaning anyone in the population has the same chance of being picked. Therefore, if all citizens are equals and the goal is to have everyone represented then random selection is as good as it gets. If democracy is understood as the will of the people then it also follows that a representative sample is as democratic as it gets short of ideal type direct democracy. Representatives selected this way will be as reflective of the demos as scientifically possible and absolutely far more so than those generated by elections under any existing system. Furthermore, I propose the demos or the qualifying pool of citizens from which selection is to take place should be defined as all residents over the age of sexual consent. No other qualifying limitations should be considered other than a basic competence test in cases where mental disabilities, etc. would prohibit an individual from fulfilling their obligation. This gives a voice to just about all regardless of legal status, including the incarcerated, people with addictions, all professional groups including manual labor, all sexual orientations and identities, all religious, political and other ideological beliefs, all races, ethnic and linguistic groups, people of all educational levels, ages, subcultures and countercultures.

What about the argument that representatives must be "qualified", e.g., have a certain level of educational attainment or passing a qualifying test other than a simple mental competence test? For example, one journal reviewer commented on this work: "leaving everything to individuals' mere voting on issues assumes that individuals already know everything. Where is the role for education, and who organizes that education?”. It is both logical and tantalizing to agree with this argument. Unfortunately it is a fallacy. If we are all equal in a democracy we are all equal to vote and represent. Establishing qualifications represents de facto disfranchisement. Poll taxes, literacy and comprehension tests are also known as the past Jim Crow laws of the racist South. Also, who designs these tests? Who determines what the qualifications should be? Nobel birth? A high school diploma? A Bachelor's degree? Logically, the Ph.D. trumps the rest and should be the minimum qualification. What about the poor that are systemically denied a quality education, 
should they also be denied voting or representative rights by the system that denied them the tools to participate? That would be a tautology. Those that insist on qualifications fundamentally have no faith in or desire for democracy. In this case the only logical egalitarian alternative system would be the one Plato outlined in the Republic.

Nevertheless, education is the foundation for a democracy, a fact ironically recognized by the founding fathers. This is why the highest quality free education based on critical pedagogy as developed by Freire (2000), McLaren (2006), and others is imperative to break the chains of backwardness and oppression, again a topic in of itself that I have addressed in my book publications given limitations of space here. Through education people will be better equipped to identify their true interests, act upon them effectively, and resist propaganda. Hopefully, it will also permit people to identify and acknowledge injustices, e.g., against those of different sexual orientations, abilities, or backgrounds. This is also the ideological reason the elite gut critical education at all levels for the masses in order to control them with a semblance of legitimacy in a system that is democratic in name only (Chomsky, 1989; Giroux, 2007).

Another comment I received from a reviewer was: "If I am chosen at random to make decisions for society as a whole, I am beholden to no one; this is a complete capitulation to arbitrariness and caprice, and would induce widespread cynicism. The whole point concerning the principled process of 'selection' of representatives is to sharpen criteria for evaluation of potential representatives' capacities to carry out broad mandates from the wider public, and to perfect procedures for control and checkup regarding their performance". First, the commentator misses the entire point that a randomly selected representative should vote based on their own views because these represent the views of many as is the whole point of random selection. The second part of that comment brings us back to the problem of many on the Left who also think in hierarchical terms where they self-appoint themselves as the leaders of the un-educated masses.

Given the above, three levels of governance should be sufficient and efficient. There would be no executive branch at any level. The people are the executive, thus, direct democracy. Should there be an executive then the door opens up once more to bribery, bias, and all kinds of undesirable influence regardless of how the executive is selected. Unfortunately, group dynamics are such that direct democracy above a local level cannot function with say a million lawmakers meeting to hash out issues. But, direct democracy can function with randomly selected lawmakers combined with direct voting on major negotiated legislative options via the internet. Legislatures at the state or regional and federal levels would be randomly selected by lottery from the pool of residents to serve a once in a life-time three year term. Terms will be staggered, scheduling terms of office so that all members of a body are not selected at the same time to avoid a pool overly influenced by strong passing sentiments. No one can serve simultaneously on more than one legislature or court nor on both a court and legislature. 
As for the legal branch at the state and federal levels, it is disingenuous to expect nine or any other small number of appointed individuals to be the Solomons of society. Who appoints a judge can determine how cases will be voted on. In addition, a judge will always have personal biases even though he or she may think they are objective. How, then, should a Supreme Court be structured assuming one should even exist. First, people cannot be trusted to always respect the fundamental principles of a democratic process. This is due to human nature that at times can be overcome by passions at the expense of reason. In fact, psychologists have confirmed that emotions typically trump logic. The 9/11 attacks have demonstrated this with the wave of Islamophobia that followed. Nor does the average person have the legal proficiency to understand many complex or technical legal issues. Therefore legally trained professionals are as needed as architects, educators, and doctors for a democratic society. Second, given the need of a legal system, a Supreme Court should be structured as the legislature. Judges would be randomly selected from a qualified pool for a one in a life-time three year term of service.

At the local level, e.g., towns and borough districts direct democracy is feasible but, all other details of structure and process must be decided by the residents. Local courts will be established filled by lottery from the state's pool of legally trained professionals. Each case will be presided by nine judges and a ten person jury. Cases will be decided by a simple majority vote of both bodies combined. At the next level of state or province there is a unicameral legislature (meaning only one House). The size could be anywhere from 201 to 1001 lawmakers depending on the size of that state's population and the number needed for a representative sample and working groups. The legislature is then filled by lottery from the pool of that state's residents. Residency should be established by living there at least one year. The state Supreme Court should be structured the same as the legislature. Judges would be randomly selected from a qualified pool of legal professionals residing in the state for a one life-time three year staggered term. The court should consist of 51 to 101 voting judges for every case although lottery could determine a sub-set of judges that would be asking the questions and facilitating the trial. In essence the other judges would be a professional jury. Limited service assures that current cultural beliefs and values are reflected in the serving pool which will be updated at regular intervals while the court's size and random selection limit influence.

In a federated political structure, each of the states receives a percentage of the seats in the national unicameral legislature proportional to that state's population. This is similar to how the number of congressional seats is currently apportioned in the United States congress. The selection of lawmakers would follow the same process as at the state level. The federal Supreme Court should consist of 501 to 1001 voting judges for every case although lottery could determine a sub-set of judges that would be asking the questions and facilitating the trial. The judges should be selected for staggered terms to avoid a pool overly influenced by strong passing sentiments of the time. In essence the other judges would be a professional jury. 


\section{COMBINING OTHER FORMS OF DIRECT DEMOCRACY WITH RANDOMLY SELECTED LEGISLATORS}

Some may argue that deliberative or discursive democracy based on the writings of Jürgen Habermas (1997) may be an alternative structure for direct democracy. Accordingly, it is suggested that public deliberations be held for deciding various issues. A choice is made by the demos when an issue is fully deliberated and consensus reached. Therefore, legislation derives legitimacy from the deliberative process. Unfortunately, a major problem with deliberative democracy is its inability to address the issue of power. Namely, how can dialogue take place in a community where those in power either refuse to allow public input and deliberation or limit the parameters of the debate in ways that render it meaningless - moral persuasion has its limits in the face of power and opposing class interests. Consequently, if the elite (even under a representative democracy) wish to limit substantive debate action would be required by the demos to force public deliberations. But, a second problem now emerges. Once a deliberation is concluded what are the guarantees those in office will actually implement the decision of those involved in the discourse? For example, think of the countless blue-ribbon committees formed by various administrations, how many recommendations have actually been implemented? Again, this raises the issue of power and opposing elites, a reality also found in representative systems.

However, the current proposals can be combined with deliberative democracy in that the two can and should be complimentary. First, as will be elaborated, it is argued direct action would be the necessary tool with which to obtain such structural changes. Second, the structures outlined here would not uproot all social institutions and accustomed modalities of life resulting in a major social experiment with unknown outcomes. Rather, we are keeping basic governing institutional structures in place but, modifying the basis upon which they are staffed e.g., via a lottery. This could be combined with various formulas of deliberative democracy. For example, Fishkin (1991) suggested decision-making by way of a deliberative opinion poll. Accordingly, a representative sample would be generated from the community to discuss an issue. The group is then polled and their recommendations forwarded to the decision makers or adopted outright.

Here, Fishkin's representative sample forming a deliberative opinion poll would in fact be the decision makers. Those citizens selected through lottery to serve on legislatures and courts would discuss and deliberate options. More importantly, they would also have the power to adopt said outcomes of deliberation by virtue of being the decision makers themselves. Therefore my proposals can incorporate various elements of direct democracy both structurally and procedurally.

The same can be said regarding participatory budgeting examples of which can be found in municipalities like Porto Alegre, Brazil (Wampler, 2009), Chicago (Lerner and Antieau, 2010) and many others around the world. In essence, municipal residents deliberate how budgets should be allocated based on which proj- 
ects are deemed important by the community. This form of direct democracy can work well and be part of the process at the local level in congruence with the proposals outlined by this paper. But, the question of scale is raised again when looking at broader governance levels, e.g., state or federal. How could citizens of a nation deliberate budget allocations? A simple solution would be Fishkin's representative sample generated to deliberate, in this case, budgets. Here it is suggested that participatory budgeting will be practiced by the randomly selected legislators who statistically represent the population. This could also be combined with internet voting, also referred to as Electronic Direct Democracy (EDD), (Behrouzi, 2005; Nixon and Koutrakou, 2007). Specifically, all the citizens of a state or the nation can propose and vote on budget allocations via the internet. It is also possible to create multiple procedural variations depending on what the people decide. For example, randomly selected legislators can deliberate a number of projects to be funded which then can be put to an internet vote that will approve or reject projects and rank them in terms of priorities.

Such a system as described here can come very close to a practical version of direct democracy when combined with EDD / internet voting given the proper safeguards at the state and federal levels (Behrouzi, 2005; Nixon and Koutrakou, 2007). Envision the following. A truly representative state or federal legislature, as proposed here, with working groups and straight up or down votes without parliamentary trickery and arcane rules, in place today, could debate a number of options for legislating on an issue. Once a basic set of options are agreed upon these could be put to a state or national referendum respectively via internet voting. This process has inherently many advantages, e.g., every major decision such as going to war or not, building schools or stadiums could be put to a popular vote. It could be plausible that certain days or times of the day are put aside for the purpose of deliberating and voting on such matters. Thus, corruption and undue influence would be limited since anyone wishing to "purchase" a vote would have to buy many more people than a senator or two as is currently done given that a single senator can block virtually any legislation from passing by putting a "hold" on it. In any case, such forms of voting should increase transparency and offer flexibility while ensuring maximum input from the demos. Clearly, many details are not outlined here because this is not meant to be a purely theoretical exercise based on one's ideology disconnected from reality. Rather, the purpose here is to broadly outline a working system that increases transparency and social justice leaving the details to the people themselves.

But, voting must be mandatory as part of one's civic obligations to the community. Remember, with privileges come obligations. Compulsion to vote may be based on financial penalties as in many West European democracies or mandated community service. Why is participation so important? When people do not vote it opens the door to influence and corruption which ultimately undermines democracy. This is the real reason the United States does not make voting mandatory arguing it is "a democratic right not to vote". Such a pseudo-right only benefits the 
elite who understand the value of participation in contrast to the poor majority, thus, allowing them to outvote the interests of the many. This is also why the history of the United States is one of resisting the expansion of the franchise.

Another positive aspect of such a political structure is the emasculation of political parties - an anathema to Marxists who believe in political parties and in many European cases participation within the political system. However, even the oligarchic founding fathers had cautioned against political parties with George Washington famously observing congress instinctively splitting into two bitter factions and warning against political parties in 1796 during his farewell address: "I have already intimated to you the danger of parties in the state [...] Let me now take a more comprehensive view, and warn you in the most solemn manner against the baneful effects of the spirit of party, generally" (G. Washington, 1796). The same sentiment against political factions was echoed in Federalist Papers 9 and 10 by Alexander Hamilton and James Madison, respectively.

Bipartisanship and polarization are but the surface problems posed by political parties especially in systems with strong parties that have centralized hierarchical structures, e.g., many European parliamentary systems. The same problems however still manifest themselves in systems where parties are looser as in the United States. For example, how democratic is it for political parties to be dominated by dynastic political families, including ironically so-called "socialists", e.g., where the father and grandfather of the current party leader and prime minister like George Papandreou of Greece were also party leaders and prime ministers? Why should the Kennedy or Bush family name, have any added influence in party or national politics? How is this any different from a political aristocracy or caste as in countries like India, therefore inherently undemocratic?

More importantly, political parties by definition represent sub-segments of society versus the whole. What some on the Left fail to recognize is this happens even with a workers' party in that there are usually multiple Left parties claiming to be the true workers' party. Simply, political parties are another larger scale special interest group and therefore seek to promote the benefit of some over others - even within the party. Specifically, within them you will find leaders, which raises the further question of whose interests are really being promoted. As soon as you get a hierarchical leadership structure you encounter the same problems of corruption and influence as with elected legislatures. These tendencies of political parties toward hierarchical organization were recognized by Robert Michels (2010 [1911]). Using the term iron law of oligarchy Michels argued that all party leaders eventually become a self-interested oligarchy. The large volume and complex nature of tasks of political parties require expert leaders with a stable tenure of office, an organizational logic that increases oligarchic tendencies. Therefore it is in the nature of elites to advance their own interests and power at the expense of those of their followers. Consequently, political parties are fundamentally undemocratic contrary to popular belief, including any so-called Left parties - is socialist prime minister George Papandreou of Greece listening to the rioting workers of his party every 
time he forces upon them new austerity measures at the behest of the IMF and European Union?

To be clear, I am not suggesting we eliminate political parties. Rather it is suggested we bypass them by letting the people deliberate and decide matters themselves absent of party or legislative leaders as under current systems of representation. There is no reason why people could not continue to organize formally around issues important to them which is technically what political parties are about. Under the new system however, the nature and function of the parties would change more toward social clubs or advisory groups etc. in that they would not be fielding candidates since decision makers would be randomly selected. Interestingly, this should also theoretically increase societal discourse. If neither parties nor political leaders get to rule themselves, they would have to increase their reliance on public discourse to promote their viewpoint. If anyone from the population could be selected as a decision maker then a group or political party would have a greater chance of seeing its agenda enacted by disseminating it and convincing the broader population of its merits. This increases the chances of the selected legislators sharing those views and acting on them.

As important, the proposed process eliminates elections for political representatives which, no matter what the intent or the quality of oversight, will be open by definition to manipulation. For example, some candidates would have greater media access then others to get their message across especially if it is along elite interests who also happen to own the mass media. Money can always find its way into the election process thus corrupting it, especially when some have and others have not. Career politicians are eliminated as well including their incumbent advantages and corruption that goes with it. For instance, incumbents are rarely defeated demonstrating power determines political outcomes which is inherently unfair if not undemocratic. Now, corporations could not "purchase" a politician as no one could know who would be selected. Combined with a limited one lifetime term of service say three years it further complicates influencing corrupt public servants. All media are also bypassed by this process which is important. Mass media by definition will express some viewpoint, either pro-capital, pro-worker, a personal opinion of some commentator, or the media's view itself. Elections however should only represent the unbiased views of the population free of any manipulation. The only legitimate role of the mass media in this case is to provide objective news information, a topic in of itself. Given that there is no such thing as bias-free representative elections, we have the paradox of elections for representatives being inherently undemocratic.

\section{Would these proposals eliminate opposing classinterests or economic antagonisms?}

Class interests and economic antagonisms would still exist. The only fundamental means through which to eliminate these is a radical socioeconomic revolu- 
tion that would uproot all existing socioeconomic structures. Such a revolution though is not possible for a myriad of reasons for the foreseeable future (which is not the focus of the paper). Nor should we be wishing for such sudden radical change because there is no clear blueprint of where it would take us. Sadly, the Left is not that well organized, rather it is in retreat globally.

What these proposals would do is severely limit the power of capital. When anyone in the population, the majority of which are workers, can govern it would no longer be possible for the elite to control the political process as outlined in this work. This is also why the founding fathers were afraid of direct democracy. If society's rules are made by political institutions then those who control those institutions make the rules. Currently, that means the wealthy. But, if average citizens rule then the power of productive property can be subdued. Theoretically, the citizen legislators and judges could even pass fundamental redistribution laws, including the expropriation of productive property.

\section{CONCLUSION: HOW DO WE IMPLEMENT THESE PROPOSALS?}

How can we implement these radical proposals? The answer according to history is direct action including sabotage, occupations, destruction of capitalist property, mass demonstrations and violent resistance against police intervention. It was through such direct action spanning generations that the labor and civil rights movements won most if not all substantive victories from the power elite including the eight-hour workday, the right to collective bargaining or simply forming a union, and civil rights just to name a few (Adamic, 2008; Asimakopoulos, 2011; Brecher, 1997; Peniel, 2006). But that was then and this is now so how could you advocate violent resistance? In fact, violence is exercised by the state to this day against its own people and those of other nations. Violence against the state is also routinely practiced to this day in many industrial democracies, e.g., Spain, Greece, Ireland, etc. (see various national news broadcasts 2008 -11 on anti-austerity clashes). In Greece the media routinely show protesters including anarchists attacking security forces in demonstrations rather than the other way around. In more extreme cases people even engaged armed rebellion as did blacks in many US cities during the ghetto revolts of the 1960s (Boesel and Rossi, 1971; Theoharis, 2006).

If workers' groups become successful and overcome the state why not simply demand outright expropriation of productive property, a political revolution in other words? If workers had such power and the historical time was ripe, then a revolution against the state to establish workers' control would be the appropriate goal. Unfortunately, this is not feasible in the foreseeable future for a number of reasons leading us back to pragmatism balanced with theoretical ideals. Demanding direct democracy is not the same as expropriating businesses. Although the elite and state would battle these changes they would be invested far less in a fight to the end as when confronted by outright wealth expropriation which is synonymous 
to political revolution. But, assume we did engage in revolution against the state. For whatever reasons, ranging from media concentration to lack of class-consciousness, there is simply not enough support from the working class population for such a revolution to be successful. The question then becomes do we wait until we develop sufficient support for that ideal revolution in the bye and bye or do we do something attainable in the here and now?

More so, assuming we revolted successfully, would people know how to function in a radically new society-remember there are far more Republicans and conservatives than Marxists and anarchists that have no clue (this includes many Democrats) what communism or anarchy are or how they are suppose to work. What would new social institutions look like if all existing ones are abolished? If we are talking about creating fundamentally new modes of life, who gets to design the system? Altering society immediately from its roots would in effect be someone's grand thought experiment. What safeguards will there be to avoid another hierarchical system or worse? How do average people learn to function in this new brave world constructed by others for them? The proposals presented here allow for relations in governance to evolve within existing institutions as incubators for these grand shifts in social modalities down the road. In other words, we would be developing a working model of counter-hegemony as proposed by Gramsci (1971) that could show people how things would work in the real world in contrast to representative systems tied to capitalism.

In the US, perhaps the impetus for such radical demands will come from the ultra conservative attacks on the working class by representatives of capital. For example, in 2011 Wisconsin's Republican governor unleashed efforts to abolish collective bargaining rights for state employees. Perhaps adult critical education and the realization that capital is in control of the political process will suffice to spark the demands outlined here. However, how one mobilizes people into direct action for such demands requires far greater analysis than space permits here. The most important point of this, and similar works, is to stimulate radical thinking that is not disconnected from existing realities. We need to think big and pragmatically.

\section{REFERENCES}

Adamic, Luis. (2008). Dynamite: The Story of Class Violence in America. Oakland, CA: AK Press.

Alter, Jonathan (2006). The Defining Moment: FDR's Hundred Days and the Triumph of Hope. New York: Simon \& Schuster.

Asimakopoulos, John (2011). Revolt! The Next Great Transformation from Kleptocracy Capitalism to Libertarian Socialism through Counter Ideology, Societal Education, and Direct Action. New Jersey: Transformative Studies Institute.

Behrouzi, Majid (2005). Democracy as the Political Empowerment of the Citizen: Direct-Deliberative e-Democracy. New York: Lexington Books. 
Boesel, David, and Peter H. Rossi, eds. (1971). Cities under Siege: An Anatomy of the Ghetto Riots, 1964-1968. New York: Basic Books.

Bouton, Terry (2007). Taming Democracy: "The People," the Founders, and the Troubled Ending of the American Revolution. Oxford: Oxford University Press.

Brecher, Jeremy (1997). Strike! Cambridge, MA: South End Press.

Bureau of Labor Statistics, U.S. Department of Labor (2009). "Table 4. Covered establishments, employment, and wages by state”, fourth quarter 2009. Washington, DC. Available at: http://www. bls.gov/news.release/pdf/cewqtr.pdf

Burnheim, John (2006). Is Democracy Possible? Sydney: Sydney University Press.

Carson, Lyn and Brian Martin (1999). Random selection in politics. Westport, CT: Praeger.

Chomsky, Noam (1989). Necessary Illusions: Thought Control in Democratic Societies. Boston: South End Press.

Chomsky, Noam (2002). Media Control: The Spectacular Achievements of Propaganda. New York: Seven Stories Press.

Domhoff, G. William (1975). The Bohemian Grove and Other Retreats: A Study in Ruling-Class Cohesiveness. New York: Harper Torchbooks.

Domhoff, G. William (2010). Who Rules America? Challenges to Corporate and Class Dominance. Sixth edition. Boston: McGraw Hill.

Freire, Paulo (2000) Pedagogy of the Oppressed. New York: Continuum, 30th anniversary edition.

Friedman, Matt (2010). "President Obama arrives in Cresskill for fundraising dinner". NJ.com, October 06. Available at: http://www.nj.com/news/index.ssf/2010/10/president_obama_arrives_in_cre. html

Giroux, A. Henry (2007). The University in Chains: Confronting the Military-Industrial-Academic Complex. New York: Paradigm Publishers.

Gramsci, Antonio (1971) Selections from the Prison Notebooks of Antonio Gramsci. Edited and translated by Quintin. Hoare and G. N. Smith. New York: International Publishers.

Guerin, Daniel (1970) Anarchism: From Theory to Practice (Mary Klopper trans.). New York: Monthly Review Press.

Habermas, Jürgen (1997). Between Facts and Norms: Contributions to a Discourse Theory of Law and Democracy. Malden: MA Polity Press.

James S. Fishkin S., James (1991). Democracy and Deliberation: New Directions for Democratic Reform. New Haven: Yale University Press.

Kropotkin, Peter (2005 [1892]). The Conquest of Bread and Other Writings (Marshall S. Shatz ed.). Cambridge: Cambridge University Press.

Lerner, Josh and Megan Wade Antieau (2010). “Chicago's \$1.3 million experiment in democracy. YES! Magazine. Available at: http://www.yesmagazine.org/people-power/chicagos-1.3-million-experiment-in-democracy.

McLaren, Peter (2006) Life in Schools: An Introduction to Critical Pedagogy in the Foundations of Education (5th Edition). Boston: Allyn \& Bacon.

Michels, Robert. (2010[1911]) Political Parties: A Sociological Study of the Oligarchical Tendencies of Modern Democracy. Whitefish, MT: Kessinger Publishing.

Mills, Wright C. (2000[1956]). The Power Elite. Oxford: Oxford University Press.

Morgenson, Gretchen and Van Natta Jr., Don (2009). "Paulson's Calls to Goldman Tested Ethics". New York Times, August 8. Available at: http://www.nytimes.com/2009/08/09/business/09paulson. html? pagewanted=1\&_r=1

Nagourney, Adam (2010). "In California bid, Whitman spends record but struggles”. The New York Times, October 1. Available at: http://www.nytimes.com/2010/10/02/us/politics/02calif.html.

Nixon, Paul G. and Vassiliki N. Koutrakou (2007) E-government in Europe: Re-booting the State. New York: Routledge. 
Peniel, Joseph E., ed. (2006). The Black Power Movement: Rethinking the Civil Rights-Black Power Era. New York: Routledge.

Rocker, Rudolf (1938). Anarcho-Syndicalism. London: Secker and Warburg.

The United States Elections Project. Department of Public and International Affairs George Mason University. (2012). Available at: http://elections.gmu.edu/index.html.

Theoharis, Jeanne (2006) “'Alabama on Avalon' rethinking the Watts uprising and the character of black protest in Los Angeles”, in Peniel E. Joseph, ed. The Black Power Movement: Rethinking the Civil Rights-Black Power Era, 27-53. New York: Routledge.

Wampler, Brian (2009). Participatory Budgeting in Brazil: Contestation, Cooperation, and Accountability. University Park, PA: Pennsylvania State University Press.

Ward, Colin (1982) Anarchy in Action. London: Freedom Press.

Washington, George (1796). "Farewell address". Available at: http://en.wikisource.org/wiki/ Washington\%27s_Farewell_Address\#20

Weber, Max (1978 [1922]) Economy and Society: An Outline of Interpretive Sociology. Edited by Guenther Roth and Claus Wittich. Berkeley: University of California Press. 